\title{
Inferring population structure and genetic diversity of the invasive alien Nootka lupin in Iceland
}

\author{
Jakub Skorupski, ${ }^{1,2}$ Magdalena Szenejko, ${ }^{1,2}$ Martyna Gruba-Tabaka, ${ }^{1,2}$ Przemysław Śmietana ${ }^{1,2}$ \& \\ Remigiusz Panicz ${ }^{3}$ \\ ${ }^{1}$ Institute of Marine and Environmental Sciences, University of Szczecin, Szczecin, Poland; \\ ${ }^{2}$ Molecular Biology and Biotechnology Centre, University of Szczecin, Szczecin, Poland; \\ ${ }^{3}$ Faculty of Food Sciences and Fisheries, Department of Meat Technology, West Pomeranian University of Technology in Szczecin, Szczecin, Poland
}

\section{Abstract}

Polar and subpolar regions are known for their particular vulnerability and sensitivity to the detrimental effects of non-indigenous species, which is well exemplified by the Nootka lupin (Lupinus nootkatensis) spread in Iceland. Since understanding the population and ecological genetics of invasive alien species offers hope for counteracting harmful biological invasions, the objective of the present study was to investigate interspecific variation in L. nootkatensis in Iceland in relation to a native population in Alaska. Moreover, we aimed to assess whether internal transcribed spacer 2 (ITS2) has sufficient phylogenetic applicability for a large-scale screening of the genetic diversity of a non-indigenous population of this species. This study, which is the first attempt to investigate the genetic diversity of the Nootka lupin in Iceland, included plant samples from eight locations in Iceland and one in Alaska. The analyses included genotyping by sequencing of the 417-nucleotide fragment of the 5.8S ribosomal RNA, ITS2 and part of the large subunit ribosomal RNA (GenBank MT026578-MT026580, MT077004). The main findings showed the presence of five previously unexplained single-nucleotide polymorphisms (SNPs); however, their discriminatory power for Icelandic populations was relatively low, since polymorphism information content (PIC) values ranged from 0.0182 to 0.0526 , with average heterozygosity 0.0296. Concomitantly, analysis of multilocus genotypes (MLG) revealed sufficient differences in MLGs variants and their frequency to form genotypic patterns unique for Alaskan and Icelandic populations, revealing an internal genetic structure of the studied group. The proposed SNP panel needs to be supplemented with other nuclear and organellar markers.
\end{abstract}

\section{Keywords}

Biological invasions; genetic diversity; ITS2; Lupinus nootkatensis; population structure; nature conservation

\section{Correspondence}

Jakub Skorupski, University of Szczecin, Institute of Marine and Environmental Sciences, Adama Mickiewicza 16 St., 70-383 Szczecin, Poland. E-mail jakub.skorupski@ usz.edu.pl

\section{Abbreviations \\ bp: base pair; $D_{S T}$ : diversity due to differentiation; $F_{I S}$ : inbreeding coefficient; $F_{I T}$ : overall fixation index; $F_{S T}$ : fixation index; GNTP: ITS2 region genotype; $G_{S T}$ : coefficient of genetic differentiation among populations; $H_{\text {obs }}$ : observed heterozygosity; $H_{s}$ : genetic diversity within population; $H_{T}$ : total genetic diversity; I: Shannon-Wiener information index; ITS2: internal transcribed spacer $2 ; K$ : average number of nucleotide differences; LD: linkage disequilibrium; MLG: multilocus genotype; $n_{e}$ : effective number of alleles; $N_{m}$ : gene flow between populations; nrDNA: nuclear ribosomal DNA; PCR: polymerase chain reaction; PIC: polymorphic information content; RAPD: random amplification of polymorphic DNA; $R_{G}$ : genotypic richness; SNP: single-nucleotide polymorphism. UPGMA: unweighted pair group method with arithmetic mean; $\Theta$ : mutation rate per bp per generation, reflecting the expected resources of neutral variation in the population; $\pi$ : nucleotide diversity}

\section{Introduction}

Invasive alien species pose serious ecological and есоnomic problems (Thuiller et al. 2008; Skorupski et al. 2017). The harm to biodiversity from biological invasions results from the fact that they exert an array of unpredictable effects-both on individual species as well as on biocenotic systems (Richardson et al. 2000;
Gallardo et al. 2019). This fact, in conjunction with the specific features of polar and subpolar ecosystems, such as relatively low diversity of native species, low temperatures that reduce the effectiveness of ecological homeostatic mechanisms, simplified trophic terrestrial networks, high rate of temperature increase due to climate change and increasing human activities and isolating geographical barriers, clearly indicates their 
particular vulnerability and sensitivity to the detrimental effects of a non-indigenous species spread (Xu et al. 2013; Bennett et al. 2015; Stefansson et al. 2016; CAFF \& PAME 2017). A good example illustrating this problem is the Nootka lupin (Lupinus nootkatensis Donn ex Sims, 1810), native to Alaska and north-east Canada and intentionally introduced to Iceland in 1885 (Schierbeck 1886). In the mid-20th century, the Nootka lupin became naturalized on the island and is now widely spread across the country, posing serious ecological threats to native flora and fauna by displacing coldadapted native plant species, and negatively impacting native pollinator communities (Bjarnason 1981; Wąsowicz et al. 2013; Willow et al. 2017; Vetter et al. 2018; Guðjohnsen \& Magnússon 2019).

Population and ecological genetics research offers hope for counteracting harmful biological invasions (Ward et al. 2008; Lawson Handley et al. 2011). Knowledge of the genetic structure of non-indigenous plant populations is helpful in determining their invasiveness potential, tracking the sources and routes of invasions; forecasting their scale and assessing the genetic consequences of invasions (Ward et al. 2008; Lawson Handley et al. 2011; Harvey-Samuel et al. 2017; Wang et al. 2017).

In this study, we tested part of the 18S-26S nrDNA region, containing a fragment of the $5.8 \mathrm{~S}$ ribosomal RNA, ITS2 and part of the large subunit ribosomal RNA (hereinafter referred to as the ITS2 region), as an inter-population genetic variation marker of invasive populations of the Nootka lupin in Iceland. This nuclear DNA region has been proven to be a useful phylogenetic marker in plants, helpful in resolving evolutionary relationships and taxonomic problems (Chen et al. 2010; Han et al. 2013; Mishra et al. 2016). High intraspecific, discriminatory ability (enough to distinguish even closely related species), short length, high efficiency for PCR amplification, high copy number of rRNA genes flanked by well-conserved rRNA genes, and the fact that ITS2 is not expressed, indicate its potential as a standard DNA barcode in plants - the only nuclear barcode available for seed plants identification (Alvarez \& Wendel 2003; Chase et al. 2007; Mäder et al. 2009; Yao et al. 2010; Li et al. 2015; Mishra et al. 2016). Many authors reported its utility for evolutionary studies in various plant groups (Alvarez \& Wendel 2003; Sonnante et al. 2003; NietoFeliner \& Rosselló 2007; Hughes et al. 2006; Chen et al. 2010; Feng et al. 2016; Wang et al. 2016; Qin et al. 2017; Zhao et al. 2018; Duan et al. 2019), including representatives of the genus Lupinus (Käss \& Wink 1997; Aïnouche et al. 2004; Eastwood et al. 2008; Mäder et al. 2009). At the same time, the degree of sequence variation of the ITSs region at the population level is, in the case of some species, high enough to assess inter-population genetic diversity (Yuan \& Küpfer 1995; Desfeux \& Lejeune 1996; Kollipara et al. 1997; Aïnouche \& Bayer 1999; Mäder et al. 2009). This also applies to some lupin species, but no data are available for L. nootkatensis in this respect (Mäder et al. 2009).

Resolving the complex history of Nootka lupin, an invasive species translocated to Iceland from its native Alaska poses serious difficulties, and preliminary population studies are needed urgently. Therefore, the main aim of the study was to investigate interspecific genetic variation in L. nootkatensis in Iceland in comparison to plants from Alaska. Moreover, we aimed to assess whether ITS2 has sufficient phylogenetic applicability for a large-scale screening of the genetic diversity of non-indigenous populations of Nootka lupin. To our knowledge this is the first study to investigate the population structure of $L$. nootkatensis in Iceland.

\section{Material and methods}

DNA was extracted from the dried leaves of 54 specimens of Nootka lupin, from eight locations in Iceland and one in Alaska, USA (as an out-group), collected in the summers of 2017 and 2019 (Fig. 1, Table 1). Total DNA was isolated using the Syngen Plant DNA Mini Kit from Syngen Biotech, following the manufacturer's protocol. DNA concentration was measured by spectrophotometric analysis (NanoDrop 2000C, Thermo Fisher).

To amplify the target sequence a standard PCR was used, with the following primers, which were designed based on the previously recognized GenBank sequences: MG236533.1 sequence of the Nootka lupin: forward primer 5'-CCGTGAACCATCGAGTCTTT-3' and reverse primer 5'-ATTCTCATGGTGGGCTTTTC-3'. Polymerase chain reaction amplification was in a $20 \mu \mathrm{l}$ volume containing $3 \mu \mathrm{l}(30 \mathrm{ng} / \mu \mathrm{l})$ of template DNA, 2X NXT Taq PCR Kit from EURx, $0.55 \mu \mathrm{M}$ of each primer and deionized water. The PCR reactions were performed in a T100TM Thermal Cycler (Bio-Rad). The amplification profile consisted of initial denaturation at $95^{\circ} \mathrm{C}$ for $5 \mathrm{~min}$, followed by 35 cycles of denaturation at $96^{\circ} \mathrm{C}$ for $10 \mathrm{~s}$, annealing at $50^{\circ} \mathrm{C}$ for $10 \mathrm{~s}$ and elongation at $72^{\circ} \mathrm{C}$ for $30 \mathrm{~s}$, and final extension at $72^{\circ} \mathrm{C}$ for $5 \mathrm{~min}$.

Amplified products were tested in a 1.5\% agarose gel for electrophoresis with SimplySafeTM (Eurx) added in TAE buffer. To visualize and document the results, the Gel DocTM XR+ system was used (Bio-Rad). Polymerase chain reaction products were subjected to Sanger sequencing, carried out from both 5' and 3' ends (3730xl DNA Analyzer from Applied Biosystems).

In order to detect variable sites obtained sequences the products were subjected to a multiple alignment 


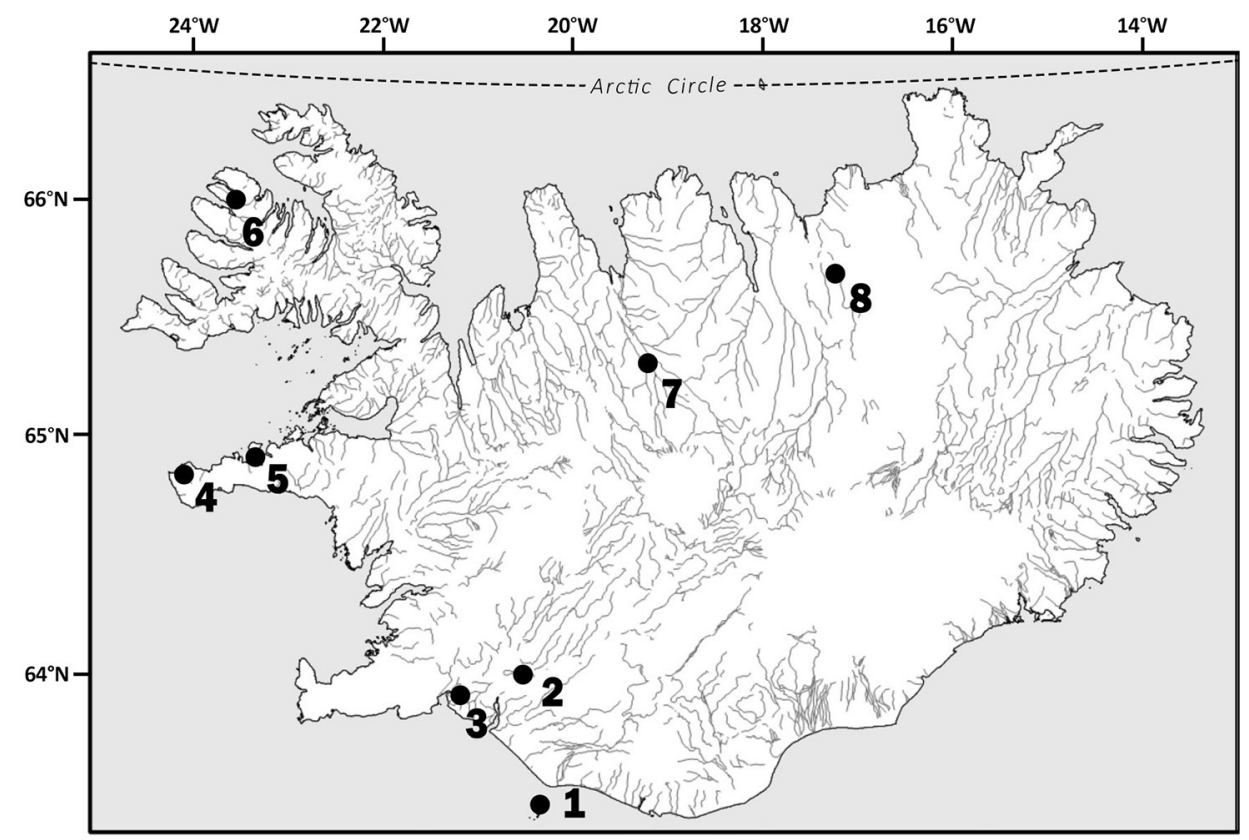

Fig. 1 Sampling locations of the Nootka lupin in Iceland (numbers correspond to the locations indicated in Table 1).

Table 1 Origin and number of tested Lupinus nootkatensis populations.

\begin{tabular}{lclc}
\hline Region & $\begin{array}{c}\text { Population } \\
\text { number }\end{array}$ & Location & $\begin{array}{c}\text { Number of } \\
\text { individuals }\end{array}$ \\
\hline Iceland & 1 & Vestmannaeyjar & 5 \\
& 2 & Gunnarsholt & 5 \\
& 3 & Eyrarbakki & 10 \\
& 4 & Útnesvegur & 9 \\
& 5 & Stykkishólmur & 9 \\
& 6 & Bolungarvík & 8 \\
Alaska & 7 & Pjóðvegur/Viðidalsvegur & 2 \\
Total & 8 & Skútustaðir & 2 \\
& 9 & Anchorage/Cook Inlet & 4 \\
\hline
\end{tabular}

by M-Coffee software (Wallace et al. 2006). Genetic diversity within the ITS2 region sequence was assessed on the basis of $\pi$ (Nei 1987), $k$ (Tajima 1983) and $\theta$, reflecting the expected resources of neutral variation in the population (Nei 1987), using DnaSP version 6 software (Rozas et al. 2017). To assess their conclusiveness and informativeness as a potential intraspecific genetic variation marker, $n_{e}$ (Kimura \& Crow 1964), $H_{o b s^{\prime}}$ PIC (Botstein et al. 1980) and I (Shannon \& Weaver 1949; Lewontin 1972) were calculated in POPGENE version 1.32 (Yeh \& Boyle 1997) and Gene-Calc (Bińkowski \& Miks 2018) software for each detected variable site.

The cumulative informative (discriminatory at the intraspecies level) value of all identified SNPs was estimated utilizing Haplotype Analysis version 1.05 (El Mousadik \& Petit 1996) based on the analysis of MLGs, in which the number of expected and observed genotypes, the number of private genotypes, $R_{G}$ (El Mousadik $\&$ Petit 1996), $H_{S}$ (Finkeldey \& Murillo 1999), $D_{S T}$ (Finkeldey \& Murillo 1999), $H_{T}$ (Finkeldey 1994) and $G_{S T}$ (Nei 1973), were used.

Using the POPGENE version 1.32 package (Yeh \& Boyle 1997), the internal genetic structure of the studied group was checked by calculating Wright's F-statistics (for all variable sites), including $F_{I S^{\prime}} F_{S T}$ and $F_{I T}$ (Wright 1978; Hartl \& Clark 1989). Gene flow between populations was estimated based on the $N_{m}$ indicator, estimated from $F_{S T}=$ $0.25\left(1-F_{S T}\right) / F_{S T}$ (Wright 1931). Additionally, Tajima's neutrality test and the Ewens-Watterson homozygosity test for each segregating site were performed to detect the possible effects of selection on inter-population allele distribution (Tajima 1989; Hedrick 2011). The first test was performed in DnaSP version 6 software, while the second in POPGENE version 1.32 software. LD and Hardy-Weinberg equilibrium were tested using Ohta's two-locus analysis for subdivided populations (Ohta 1982) and POPGENE version 1.32 software. POPGENE version 1.32 was also used to test the internal genetic subdivision of the studied group. To illustrate genetic relations among populations, a dendrogram based on Nei's (1972) genetic distance, calculated in POPGENE version 1.32 software, was constructed by the UPGMA method in MEGA version 10.1.7 software (Kumar et al. 2018). 
A chi-squared statistics test was used to assess the significance of Hardy-Weinberg disequilibrium, as well as results of the Ohta's test (POPGENE version 1.32). Differences in genotypes frequencies calculated for different populations were tested for statistical significance by the method developed by Zar (2009), using Student's $t$-test.

\section{Results and discussion}

A 417 bp gDNA sequence of the Nootka lupin ITS2 region was submitted to GenBank under accession number MT026578-MT026580 and MT077004. Within this nucleotide sequence five variable sites were detected: four transitions $(10 \mathrm{C}>\mathrm{T}, 15 \mathrm{C}>\mathrm{T}, 88 \mathrm{C}>\mathrm{T}, 332 \mathrm{G}>\mathrm{A})$ and one transversion (167C>A; nucleotide numbering according to the sequence MT077004). The proportion of polymorphic sites is equal to 0.012 . There are no other studies describing polymorphisms in the 18S-26S nrDNA sequence in the Nootka lupin. However, Aïnouche $\delta$ Bayer (1999) reported 37 variable sites in the ITS2 for 44 Lupinus taxa, of which 17 are potentially informative. The same authors identified seven variable sites, including four that were potentially informative, in the 5.8 cistron in 25 Lupinus taxa. Eastwood et al. (2008) reported 169 variable sites, including 131 parsimony informative sites, in the 5.8S subunit and flanking internal transcribed spacers ITS 1 and ITS2 in Lupinus genus. The obtained values of indexes measuring the DNA polymorphism- $\pi=$ $0.0004, k=0.1828, \theta=0.0023$-indicate an excess of low-frequency polymorphisms and low genetic diversity in the studied group (Tajima 1989; Goodall-Copestake et al. 2012).

Tajima's $D$ value is equal to -1.6986 , which may suggest either recent population expansion or purifying selection (Tajima 1989; Nei \& Kumar 2000), although without statistical significance $(0.10>p>0.05)$. The Ewens-Watterson test for neutrality of individual segregating sites showed that the $F$ value (sum of square of allelic frequency) in no case exceeded the lower and upper limit of the $95 \%$ confidence region, the expected $F$ value in the five variable sites that were analysed (Fig. 2). Such results indicate that the Hardy-Weinberg homozygosity in a given sample is consistent with the equilibrium homozygosity under neutral theory, and there is no differential selection against the allelic variants (Watterson 1977; Hedrick 2011). These findings are confirmed by results of the Ohta's two-locus analysis (Ohta 1982). The obtained average values for the components of the total variance of dilocus LD $\left(D_{I S 2}=0.0002, D_{S T 2}=0.0139, D_{I S 2}^{\prime}=\right.$ $\left.0.0143, D_{S T 2}^{\prime}=0.0002\right)$ meet the condition $D_{S T 2}>D_{I S 2}$ and $D_{I S 2}^{\prime}>D_{S T 2}^{\prime}$ indicating that the relationships among

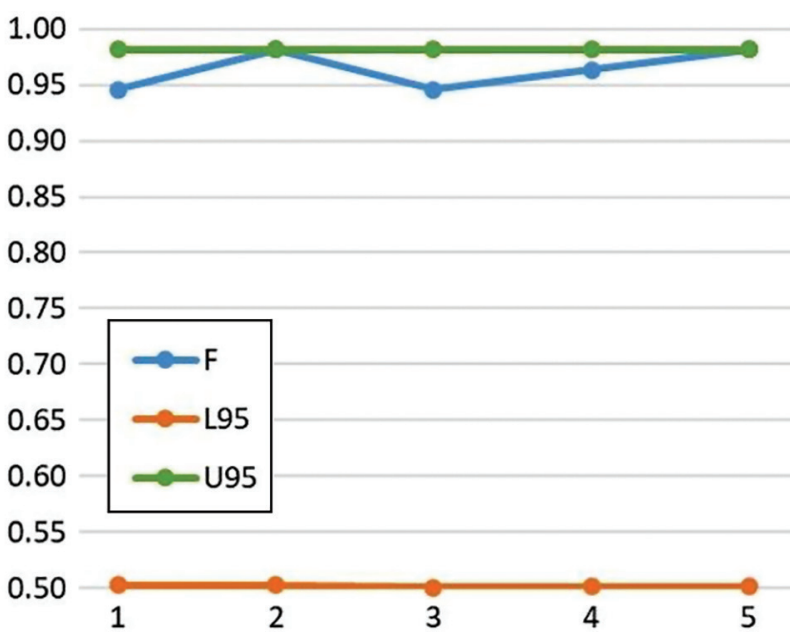

Fig. 2 Ewens-Watterson test for neutrality for identified variable ITS2 region sites in the Nootka lupin (F: observed homozygosity; U95/L95: upper/lower limits of expected $F$ values at $95 \%$ confidence level).

variable sites result from limited migration and genetic drift and not from epistatic natural selection. Only polymorphic site $88 \mathrm{C}>\mathrm{T}$ exhibited Hardy-Weinberg disequilibrium $\left(\chi^{2}=38.5714, d f=8, p<0.0001\right)$. All studied groups were in the multilocus Hardy-Weinberg equilibrium, as no statistically significant departures from the Hardy-Weinberg rule were found.

The values of basic indicators characterizing an inter-population differentiating power of the segregating sites detected within the ITS2 region are summarized in the Table 2 . The obtained average value of observed heterogeneity, PIC and I, equal to 0.0296, 0.0355 and 0.0902, respectively, indicate the low usability of the identified single SNPs as potential genetic markers and the low variety of their alleles in the studied group (Hildebrand et al. 1992). According to a commonly accepted interpretation, the five identified segregating sites can be categorized as a single nucleotide polymorphism rather than mutations, as their incidence exceeds the 1\% threshold (Aggrey \& Okimoto 2003) and equals $6 \%$ for $10 \mathrm{C}>\mathrm{T}, 4 \%$ for $88 \mathrm{C}>\mathrm{T}$ and $167 \mathrm{C}>\mathrm{A}$, and $2 \%$ for $15 \mathrm{C}>\mathrm{T}$ and $332 \mathrm{G}>\mathrm{A}$ in the studied group. Accordingly, data on a single variable site and combined five variable sites showed the highest DNA polymorphism at $10 \mathrm{C}>\mathrm{T}$, while the lowest polymorphism was found in the case of $15 \mathrm{C}>\mathrm{T}$ and $332 \mathrm{G}>\mathrm{A}$. Nevertheless, all of them separately are far from the critical limit of heterozygosity determined to $70 \%$, above which the marker is considered highly polymorphic (Ott 1992). Values of $n_{e}$ are, in the case of each variable site, close to 1 , which is the lowest possible value for diallelic loci. Such a situation occurs when one allele dominates in terms of frequency over the other that is very rare (Weir 1990). 
As SNPs are diallelic markers, PIC value of a single SNP cannot exceed 0.5 (Kruglyak 1997; Kawuki et al. 2009). It is therefore recommended that several SNP sites are considered simultaneously (SNP panels, MLGs, haplotypes), since the cumulative level of polymorphism is usually increased (Kawuki et al. 2009). This has been proven for many plant species, including rye (Secale cereale L.), grapevine (Vitis vinifera L.), maize (Zea mays L.) and cassava (Manihot esculenta Crantz) (Ching et al. 2002; Salmaso et al. 2004; Hamblin et al. 2007; Varshney et al. 2007; Kawuki et al. 2009). For each variable site two alleles were detected in the present study, while the number of identified monolocus genotypes varies from two, in case of $10 \mathrm{C}>\mathrm{T}, 15 \mathrm{C}>\mathrm{T}, 167 \mathrm{C}>\mathrm{A}$ and

Table 2 Genetic diversity indicators for the detected ITS2 region variable sites in Lupinus nootkatensis.

\begin{tabular}{lcccc}
\hline Variable site & \multicolumn{4}{c}{ Parameter } \\
\cline { 2 - 5 } & $n_{e}$ & $P I C$ & $H_{\text {obs }}$ & $I$ \\
\hline $10 \mathrm{C}>\mathrm{T}$ & 1.0571 & 0.0526 & 0.0556 & 0.1269 \\
$15 \mathrm{C}>\mathrm{T}$ & 1.0187 & 0.0182 & 0.0185 & 0.0526 \\
$88 \mathrm{C}>\mathrm{T}$ & 1.0571 & 0.0526 & 0.0185 & 0.1269 \\
$167 \mathrm{C}>\mathrm{A}$ & 1.0377 & 0.0357 & 0.0370 & 0.0922 \\
$332 \mathrm{G}>\mathrm{A}$ & 1.0187 & 0.0182 & 0.0185 & 0.0526 \\
Mean & 1.0379 & 0.0355 & 0.0296 & 0.0902 \\
Standard deviation & 0.0192 & 0.0172 & 0.0166 & 0.0372 \\
\hline
\end{tabular}

$332 \mathrm{G}>\mathrm{A}$, to 3 , in case of $88 \mathrm{C}>\mathrm{T}$. Genotypes and alleles frequencies are summarized in Table 3.

Multilocus analysis revealed six observed MLGs, while the number of expected MLGs is 48. Populations 1, 2, 4, 6, 7 and 8 are monogenous and share the same ITS2 region genotype (GNTP1), while populations 3, 5 and 9 are polygenous and are characterized by four private genotypes (Table 4). The most common genotype is GNTP1; genotypes GNTP2 and GNTP5 are nearly 24 times less frequent; while GNTP3, GNTP4 and GNTP6 are 47 times less frequent. The overall picture of inter-population genotype differences is demonstrated by genotype frequency patterns of all the identified variable sites for specific populations. This indicates that genotypes other than GNTP1 constitute as much as $75 \%$ of the genotypes found in the Alaskan population, $30 \%$ in Icelandic populations 3 and $11 \%$ in Icelandic population 5 . The average frequency of these genotypes for the Icelandic populations is $8 \%$. The overall difference between genotype frequency patterns between plants from Alaska and plants from Iceland (grouped together) is statistically significant $(t=4.622$, $d f=5, p=0.0057)$. Pairwise comparisons reveal statistically significant differences between populations 1 and $3(t=3.289, d f=10, p=0.008), 1$ and $9(t=4.622, d f=5$, $p=0.0057), 2$ and $3(t=3.289, d f=10, p=0.008), 2$ and $9(t=4.622, d f=5, p=0.0057), 3$ and $4(t=3.289, d f=10$, $p=0.008), 3$ and $6(t=3.289, d f=10, p=0.008), 3$ and 7 $(t=3.463, d f=10, p=0.006), 3$ and $8(t=3.463, d f=10$,

Table 3 Frequencies of identified monolocus genotypes and alleles in identified variable sites of the Lupinus nootkatensis ITS2 region.

\begin{tabular}{|c|c|c|c|c|c|c|c|c|c|c|}
\hline Genotype & \multicolumn{2}{|c|}{$10 C>T$} & \multicolumn{2}{|c|}{$15 C>T$} & \multicolumn{2}{|c|}{$88 \mathrm{C}>\mathrm{T}$} & \multicolumn{2}{|c|}{$167 C>A$} & \multicolumn{2}{|c|}{$332 \mathrm{G}>\mathrm{A}$} \\
\hline$\overline{C C}$ & \multicolumn{2}{|c|}{0.9444} & \multicolumn{2}{|c|}{0.9815} & \multicolumn{2}{|c|}{0.9630} & \multicolumn{2}{|c|}{0.9630} & \multicolumn{2}{|c|}{-} \\
\hline CT & \multicolumn{2}{|c|}{0.0556} & \multicolumn{2}{|c|}{0.0185} & \multicolumn{2}{|c|}{0.0185} & \multicolumn{2}{|c|}{ - } & \multicolumn{2}{|c|}{ - } \\
\hline TT & \multicolumn{2}{|c|}{-} & \multicolumn{2}{|c|}{-} & \multicolumn{2}{|c|}{0.0185} & \multicolumn{2}{|c|}{ - } & \multicolumn{2}{|c|}{ - } \\
\hline CA & \multicolumn{2}{|c|}{ - } & \multicolumn{2}{|c|}{-} & \multicolumn{2}{|c|}{ - } & \multicolumn{2}{|c|}{0.0370} & \multicolumn{2}{|c|}{ - } \\
\hline GG & \multicolumn{2}{|c|}{ - } & \multicolumn{2}{|c|}{ - } & \multicolumn{2}{|c|}{ - } & \multicolumn{2}{|c|}{-} & \multicolumn{2}{|c|}{0.9815} \\
\hline GA & \multicolumn{2}{|c|}{ - } & \multicolumn{2}{|c|}{ - } & \multicolumn{2}{|c|}{ - } & \multicolumn{2}{|c|}{-} & \multicolumn{2}{|c|}{0.0185} \\
\hline \multirow[t]{2}{*}{ Allele } & c & T & C & T & C & T & C & A & G & A \\
\hline & 0.9722 & 0.0278 & 0.9907 & 0.0093 & 0.9722 & 0.0278 & 0.9815 & 0.0185 & 0.9907 & 0.0093 \\
\hline
\end{tabular}

Table 4 Identified genotypes of the ITS2 region in the Lupinus nootkatensis (only variable sites are shown; private genotypes marked in boldface).

\begin{tabular}{lccccccccccccc}
\hline \multicolumn{1}{c}{ Genotype } & \multicolumn{10}{c}{ Frequency in population } \\
\hline Name & Sequence & 1 & 2 & 3 & 4 & 5 & 6 & 7 & 8 & $1-8$ & 9 & Total \\
\hline GNTP1 & 5'-CC-CC-CC-CC-GG-3' & 1.0000 & 1.0000 & 0.7000 & 1.0000 & 0.8889 & 1.0000 & 1.0000 & 1.0000 & 0.9200 & 0.2500 & 0.8704 \\
GNTP2 & 5'-CC-CC-CC-CA-GG-3' & 0.0000 & 0.0000 & $\mathbf{0 . 2 0 0 0}$ & 0.0000 & 0.0000 & 0.0000 & 0.0000 & 0.0000 & 0.0400 & 0.0000 & 0.0370 \\
GNTP3 & 5'-CC-CC-CT-CC-GG-3' & 0.0000 & 0.0000 & 0.0000 & 0.0000 & 0.0000 & 0.0000 & 0.0000 & 0.0000 & 0.0000 & $\mathbf{0 . 2 5 0 0}$ & 0.0185 \\
GNTP4 & 5'-CC-CC-TT-CC-GG-3' & 0.0000 & 0.0000 & 0.0000 & 0.0000 & 0.0000 & 0.0000 & 0.0000 & 0.0000 & 0.0000 & $\mathbf{0 . 2 5 0 0}$ & 0.0185 \\
GNTP5 & 5'-CT-CC-CC-CC-GG-3' & 0.0000 & 0.0000 & 0.1000 & 0.0000 & 0.0000 & 0.0000 & 0.0000 & 0.0000 & 0.0200 & 0.2500 & 0.0370 \\
GNTP6 & 5'-CT-CT-CC-CC-GA-3' & 0.0000 & 0.0000 & 0.0000 & 0.0000 & $\mathbf{0 . 1 1 1 1}$ & 0.0000 & 0.0000 & 0.0000 & 0.0200 & 0.0000 & 0.0185 \\
\hline
\end{tabular}


$p=0.006), 4$ and $9(t=4.622, d f=5, p=0.0057), 5$ and 9 $(t=2.660, d f=11, p=0.0239), 6$ and $9(t=4.622, d f=5$, $p=0.0057), 7$ and $9(t=4.622, d f=5, p=0.0057)$ and, 8 and $9(t=4.622, d f=5, p=0.0057)$.

Genetic differentiation is illustrated by compounds of Nei's (1973) genetic statistics, including $H_{T^{\prime}} H_{S^{\prime}} D_{S T}$ and $G_{S T^{\prime}}$ calculated for each variable site and averaged for individual populations. Our results, summarized in Table 5, indicate that $27.2 \%\left(G_{S T}\right)$ of the total genetic diversity in the Nootka lupin, measured by identified ITS2 region SNPs, came from genetic diversity between populations, while $72.8 \%$ came from genetic diversity among plants within populations. For all grouped Icelandic populations these values were $13.4 \%$ and $86.6 \%$, respectively, while for the Alaskan population they were $28.7 \%$ and $71.3 \%$, respectively. These values are indicative of low genetic differentiation between the sampled populations. This is supported by the values of the total genetic diversity distributed among populations $\left(D_{S T}\right)$, which range from 0.0016 to 0.0116 for the populations from Iceland $(0.0216$ for grouped non-indigenous populations) and is 0.0224 for the population from Alaska. Population differentiation may be, in this case, reduced by their isolation from each other and resulting limited migration (White et al. 2007). On the other hand, differences between populations from Iceland are much less pronounced than differences between all analysed non-indigenous populations taken together and the population of Alaska. This, as further indicated by the genotypic richness, expressing the number of genotypes found in a population corrected for sample size, is over 9.5 times greater for the indigenous Alaskan population than for the grouped populations sampled in Iceland. Similarly, the mean genetic distance between individuals from

Table 5 Results of genetic differentiation analysis of MLGs for the ITS2 region in L. nootkatensis.

\begin{tabular}{lcccccc}
\hline Population & $A^{\mathrm{a}}$ & $D^{\mathrm{b}}$ & $H_{S}$ & $D_{S T}$ & $H_{T}$ & $G_{S T}$ \\
\hline 1 & 1 & 0.0000 & 0.0000 & 0.0040 & 0.0040 & 1.0000 \\
2 & 1 & 0.0000 & 0.0000 & 0.0040 & 0.0040 & 1.0000 \\
3 & 3 & 0.7333 & 0.0852 & 0.0116 & 0.0968 & 0.1201 \\
4 & 1 & 0.0000 & 0.0000 & 0.0071 & 0.0071 & 1.0000 \\
5 & 2 & 0.4000 & 0.0329 & 0.0064 & 0.0394 & 0.1638 \\
6 & 1 & 0.0000 & 0.0000 & 0.0063 & 0.0063 & 1.0000 \\
7 & 1 & 0.0000 & 0.0000 & 0.0016 & 0.0016 & 1.0000 \\
8 & 1 & 0.0000 & 0.0000 & 0.0016 & 0.0016 & 1.0000 \\
9 & 4 & 0.6667 & 0.0556 & 0.0224 & 0.0779 & 0.2871 \\
Mean & 1.6667 & 0.2000 & & & & 0.2724 \\
Total & & & 0.1737 & 0.0650 & 0.2387 & \\
$1-8^{c}$ & 4 & 0.2279 & 0.1400 & 0.0216 & 0.1616 & 0.1335 \\
\hline
\end{tabular}

${ }^{a}$ Number of different genotypes detected in each population. ${ }^{b}$ Mean genetic distance between individuals. 'Grouped Icelandic populations.
Alaska is over 2.9 greater than that between plants from Iceland.

A somewhat similar pattern of intra- and inter-population genetic diversity was found in the white lupin (Lupinus albus L.), for which $92 \%$ of allelic diversity was attributed to individuals within populations, while allelic diversity distributed among populations amounts to only $8 \%$ (Atnaf et al. 2017). Our results, supported by the abovementioned observation, have important implications for further genomic analyses, including studies involving high-throughput sequencing and genomic selection.

The average genetic distance between the plants $(D)$ was 0.2 , with the lowest values in the completely monomorphic (in terms of ITS2 region sequence) populations $1,2,4,6,7$ and 8 . The maximum genetic distance between individuals was registered in Eyrarbakki $(D=0.7333)$. Interestingly, value of the mean genetic distance between individuals of the Icelandic invasive populations $(0.2279)$ is almost equal to that obtained by Vyšniauskienè et al. (2011) for non-indigenous populations of the large-leaved lupin (Lupinus polyphyllus Lindl.) in Lithuania (0.272), calculated for RAPD polymorphism in 192 plants.

The mean value of the fixation index, measuring the difference between the expected and observed heterozygosity of populations compared to the total analysed group is 0.1522 , which indicates a moderately high level of genetic differentiation among populations and structuring of the studied group (Wright 1978). The value of $F_{I S}=0.0366$ suggests a slight excess of homozygotes within populations, while $F_{I T}=0.1832$ indicates the same for the entire studied group. Both indicators show a moderate departure from the Hardy-Weinberg equilibrium across all populations and within all studied populations taken together (Balloux et al. 2003). Results of the Wright's $F$-statistics are summarized in Table 6. Increased frequency of homozygotes, at the level of a single population and at the level of the whole studied group, is regarded as evidence for subdivision of the latter (Wahlund 1928). However, the deviation from the Hardy-Weinberg equilibrium described above is small enough (deviation at an

Table 6 Summary of the F-statistics at all variable sites.

\begin{tabular}{lcccc}
\hline Variable site & $F_{I S}$ & $F_{I T}$ & $F_{S T}$ & $N_{m}$ \\
\hline 1 & -0.1013 & -0.0263 & 0.0681 & 3.4195 \\
2 & -0.0588 & -0.0062 & 0.0497 & 4.7812 \\
3 & 0.4667 & 0.6522 & 0.3478 & 0.4688 \\
4 & -0.1111 & -0.0112 & 0.0899 & 2.5313 \\
5 & -0.0588 & -0.0062 & 0.0497 & 4.7812 \\
Mean & 0.0366 & 0.1832 & 0.1522 & 1.3927 \\
\hline
\end{tabular}


absolute value of $3.4 \%$ for the inbreeding coefficient, and $18.3 \%$ for the overall fixation index) that the studied populations stay close to what is expected under panmixia, or high rate of clonal reproduction and self-pollination (Balloux et al. 2003). Our results are therefore consistent with the findings of Baldursson (1995), who pointed out that L. nootkatensis in Iceland depends on cross-pollination to a lesser extent than self-fertilization, which accounts for $70 \%$ of all pollination cases.

The number of migrant gametes among populations per generation $\left(N_{m}\right)$ is moderately low, amounting to 1.3927. As there are obvious geographical barriers between the Alaskan and Icelandic populations (and assuming that the significance of modern introductions is negligible), there is much more conclusiveness in the gene flow rate between non-indigenous populations, which may reflect their inter-population genetic differentiation due to dispersal on newly occupied territories. Icelandic populations are characterized by an average value of gene flow equal to 1.6231, while the Alaskan figure is 0.6441 . It has been shown that restricted dispersal is expressed by lower estimates of $N_{m}$ and higher estimates of $F_{S T}$ compared with wide dispersal (Bohonak et al. 1998). Whitlock \& McCauley (1999) demonstrated that, since gene flow depends on the effective reproduction of migrants in the new location, the movement of genes does not necessarily have to be reflected by direct measures of dispersal. This may be particularly important in the case of invasive alien species, and for Icelandic populations it may be additionally explained by the planned and large-scale (e.g., aerial seeding by airplanes) use of Nootka lupin homogeneous seeds for revegetation and protection against soil erosion, carried out from the 1960s by the Soil Conservation Service of Iceland, the Iceland Forestry Service and the Icelandic Road and Coastal Administration (Thorsson \& Hlidberg 1997; Olgeirsson 2007; Benediktsson 2015).

The UPGMA dendrogram (Fig. 3), constructed on the basis of Nei's genetic distance values (summarized in Table 7), reveals the existence of four distinct clusters not

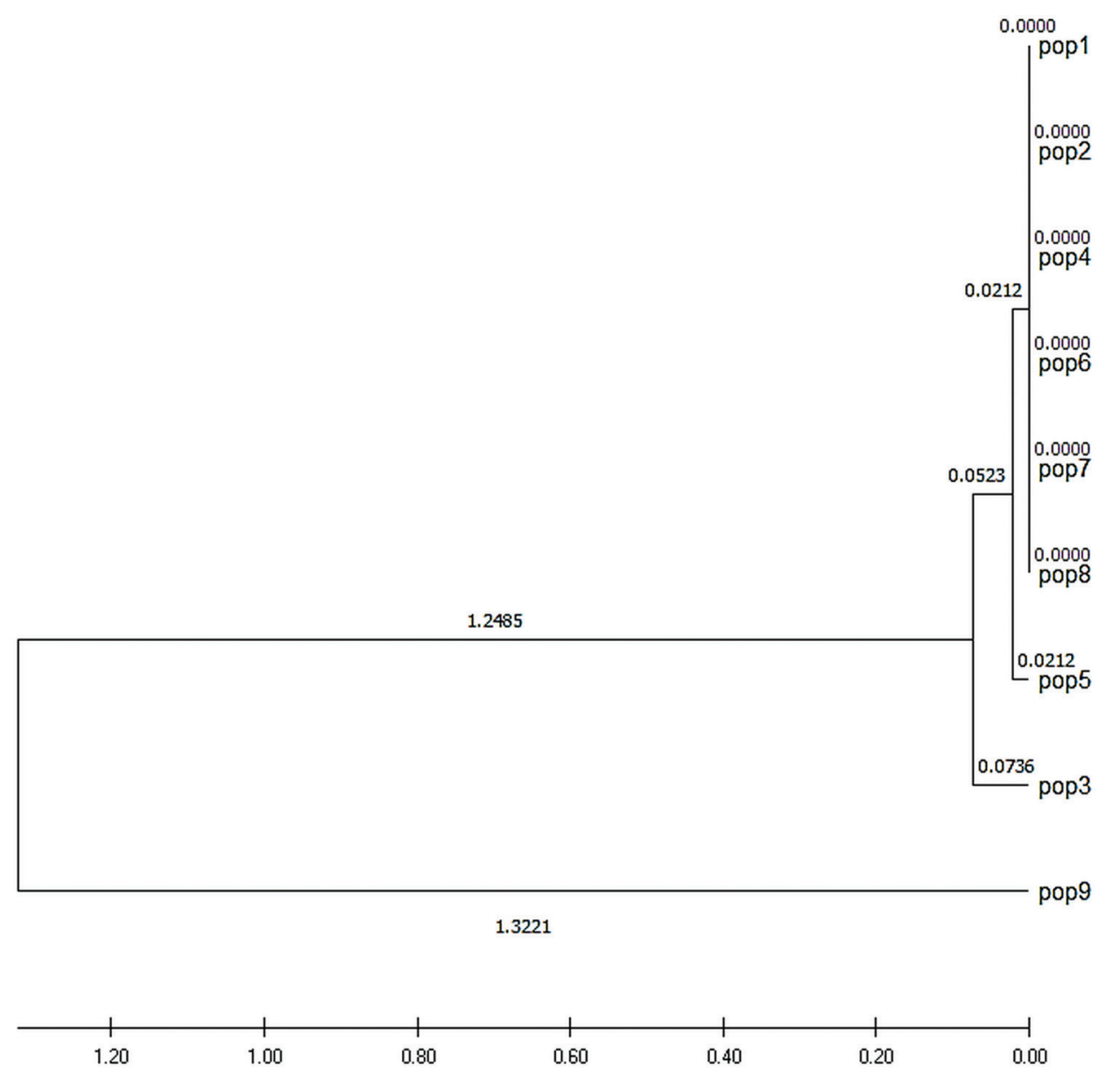

Fig. 3 UPGMA dendrogram from Nei's genetic distance (values indicated at branches) among the nine tested populations of Lupinus nootkatensis. 
Table 7 Pairwise population matrix of Nei's genetic distance.

\begin{tabular}{|c|c|c|c|c|c|c|c|c|c|}
\hline Population & 1 & 2 & 3 & 4 & 5 & 6 & 7 & 8 & 9 \\
\hline 1 & - & & & & & & & & \\
\hline 2 & 0.0000 & - & & & & & & & \\
\hline 3 & 0.0022 & 0.0022 & - & & & & & & \\
\hline 4 & 0.0000 & 0.0000 & 0.0022 & - & & & & & \\
\hline 5 & 0.0014 & 0.0014 & 0.0034 & 0.0014 & - & & & & \\
\hline 7 & 0.0000 & 0.0000 & 0.0022 & 0.0000 & 0.0014 & 0.0000 & - & & \\
\hline 8 & 0.0000 & 0.0000 & 0.0022 & 0.0000 & 0.0014 & 0.0000 & 0.0000 & - & \\
\hline 9 & 0.0314 & 0.0314 & 0.0341 & 0.0314 & 0.0334 & 0.0314 & 0.0314 & 0.0314 & - \\
\hline
\end{tabular}

fully reflecting geographical proximity, which is usually a key factor influencing the genetic relatedness of populations (Wright 1943). The first cluster groups populations $1,2,4,6,7$ and 8 (cluster I), the second groups populations 3 (cluster II), the third groups populations 5 (cluster III) and the fourth groups populations 9 (cluster IV). The last one represents plants from Alaska and, as expected, is of an out-group character, genetically most distant to all others. Post-introduction changes in genetic variability in invasive plant species, such as genetic drift, founder effects and responses to novel selection pressures, create differences between individuals in the natural range of the species and those introduced from outside that natural range, and also lead to changes in the genetic structure of introduced populations (Stout et al. 2015). It can be expressed by lower values of genetic diversity indices ( $H_{S}$ and $H_{T}$ in this study) in these populations compared to natural ones, as shown by Wilson et al. (2009), Jogesh et al. (2015), Estoup et al. (2016) and Smith et al. (2020).

Clear differences between the Alaskan and Icelandic plants (populations $1-8$ considered together) concern genotype frequency patterns, indicators of genetic differentiation analysis of MLGs, as well as Wright's F-statistics. Differences between populations from Iceland are much less expressed and account for only $5.6 \%$ of the genetic distance between plants from Alaska and plants from Iceland. Complete homogeneity and genetic identity with respect to polymorphic sites within the ITS2 region of plants in cluster I can be explained by the fact that the locations of most of its populations (populations 2, 7 and 8 in land reclamation areas and populations 4 and 6 along roadsides) coincide with areas where planned sowing was carried out over the years by the Icelandic state (Olgeirsson 2007; Guðjohnsen \& Magnússon 2019). It can be expected that large-scale use of homogeneous seed material results in founder effects (Ward et al. 2008). In turn, the reasons for genetic distinctness of cluster II and III can be seen in the location of sites occupied by populations 3 and 5 . In both cases, of key importance can be the vicinity of urban centres (the Greater Reykjavík area in the case of population 3 and Stykkishólmur in the case of population 5), and the use of a variety of seed material by individual owners of home gardens planting them with the Nootka lupin for decorative purposes (Benediktsson 2015).

\section{Conclusion}

The main finding of the present study is detection of five previously unknown single nucleotide polymorphisms in the ribosomal DNA spacer 2 regions in the Nootka lupin. Their usefulness to detect genetic variation within non-indigenous populations in Iceland is very limited (measured for individual SNP and SNP haplotypes) because of the low discriminatory power of the identified SNPs at an inter-population level and the high genetic homogeneity of Icelandic populations. At the same time, the genetic distance between plants from Alaska and plants from Iceland is sufficient to identify the non-indigenous population. This is best illustrated by the average genetic distance, which is 35.8 times greater between the tested Alaskan population and the grouped Icelandic populations than between the Icelandic populations; also by the differences in MLG variants and their frequency, forming genotypic patterns unique for each indicated group.

This study is the first attempt to investigate the genetic diversity of L. nootkatensis in Iceland. To establish a molecular tool that can screen the genetic diversity of non-indigenous populations of this species on a large scale, the SNP panel should be supplemented with polymorphisms in the sequences of other genome regions. The discriminatory power of combined nuclear and organellar markers over markers based on an individual genomic region has been proven for many species (Gamache et al. 2003; Heuertz et al. 2004; Tollefsrud et al. 2009). Further studies are needed to develop a multilocus marker of inter-population, genetic variation 
of invasive populations of the Nootka lupin. The ongoing transition from genetics to genomics increases the popularity of genome-wide and reduced-representation techniques, such as a restriction site-associated DNA sequencing (RAD-seq) or high-throughput sequencing, allowing researchers to uncover a finer population structure than microsatellites do, with a smaller sample size (Jeffries et al. 2016; Stronen et al. 2019). A genomic approach has recently been used successfully to study the genetic structure of white lupin and narrow-leafed lupin (Lupinus angustifolius L.; Książkiewicz et al. 2017; Zhou et al. 2018; Hufnagel et al. 2020).

Despite the low value of the ITS2 region's SNPs as inter-population genetic variation markers of invasive populations of the Nootka lupin in Iceland, they can help to explain the evolutionary processes to which this nrDNA region is subject to following introduction. Spatio-temporal demographic dynamics of L. nootkatensis, initiated by recent human-caused range changes, also may result in generating new patterns of genetic variation within and between populations from a plant's native range and from invaded areas. Research results indicate the possible influence of differentiation due to isolation by geographic distance (limited migration), genetic drift and recent population expansion shaping the ITS2 region polymorphism in the new environment. This, in turn, leads to the conclusion that further investigation is necessary to identify a possible barcode overlap occurring in the case of the considered sequence in the Lupinus genus.

\section{Acknowledgements}

The authors wish to thank to Mr Sławomir Keszka, Ms Bożena Kościk and Mr Henryk Kościk who provided samples from Alaska, and the anonymous reviewers whose comments and suggestions helped improve this manuscript.

\section{Disclosure statement}

The authors report no conflict of interests.

\section{Funding}

Sampling in Iceland was possible thanks to the project Exchange of Knowledge, Experiences and Best Practices in Study and Control of the Invasive Alien Species Populations in Iceland and Poland, financed by the Financial Mechanism of the European Economic Area (EEA) 20092014 and the National Fund for Environmental Protection and Water Management (Poland).

\section{References}

Aggrey S.E. \& Okimoto R. 2003. Genetic markers: prospects and applications in genetic analysis. In W.M. Muir \& S.E. Aggrey (eds.): Poultry genetics, breeding and biotechnology. Pp. 419-438. Wallingford, UK: CABI Publishing.

Aïnouche A., Bayer R.J. \& Misset M.-T. 2004. Molecular phylogeny, diversification and character evolution in Lupinus (Fabaceae) with special attention to Mediterranean and African lupins. Plant Systematics and Evolution 246, 21 1-222, doi: 10.1007/s00606-004-0149-8.

Aïnouche A.K. \& Bayer R. 1999. Phylogenetic relationships in Lupinus (Fabaceae: Papilionoideae) based on internal transcribed spacer sequences (ITS) of nuclear ribosomal DNA. American Journal of Botany 86, 590-607, doi: $10.2307 / 2656820$.

Alvarez I. \& Wendel J. 2003. Ribosomal ITS sequences and plant phylogenetic inference. Molecular Phylogenetics and Evolution 29, 417-434, doi: 10.1016/S1055-7903(03)00208-2.

Atnaf M., Yao N., Martina K., Dagne K., Wegary D. \& Tesfaye K. 2017. Molecular genetic diversity and population structure of Ethiopian white lupin landraces: implications for breeding and conservation. PLoS One 12, e0188696. doi: 10.1371/journal.pone.0188696.

Baldursson S. 1995. Frjóvgun og fræesenting alaskalúpínu. (Fertilization and seed set in Nootka lupin.) In B. Magnusson (ed.): Liffræði alaskalúpinu (Lupinus nootkatensis). Vöxtur, fræmyndun, efnainnihald og áhrif sláttar. (Biological studies of Nootka lupin [Lupinus nootkatensis] in Iceland. Growth, seed set, chemical content and effect of cutting.) Pp. 38-43. Reykjavik: Rannsóknastofnun Landbúnaðarins.

Balloux F., Lehmann L. \& de Meeûs T. 2003. The population genetics of clonal and partially clonal diploids. Genetics 164, 1635-1644.

Benediktsson K. 2015. Floral hazards: Nootka lupin in Iceland and the complex politics of invasive life. Geografiska Annaler Series B, Human Geography 97, 139-154, doi: 10.1111/ geob. 12070

Bennett J.R., Shaw J.D., Terauds A., Smol J.P., Aerts R., Bergstrom D.M., Blais J.M., Cheung W.W.L., Chown S.L., Lea M.-A., Nielsen U.N., Pauly D., Reimer K.J., Riddle M.J., Snape I., Stark J.S., Tulloch V.J. \& Possingham H.P. 2015. Polar lessons learned: long-term management based on shared threats in Arctic and Antarctic environments. Frontiers in Ecology and the Environment 13, 316-324, doi: 10.1890/140315.

Bińkowski J. \& Miks S. 2018. Gene-Calc (computer software). Accessed on the internet at gene-calc.pl on 6 March 2020

Bjarnason H. 1981. Lúpínan frá Alaska. (Lupine from Alaska.) Lesbók Morgunblaðsins 33, 6-7.

Bohonak A.J., Davies N., Roderick G.K. \& Villablanca F.X. 1998. Is population genetics mired in the past? Trends in Ecology $\theta$ Evolution 13, 360, doi: 10.1016/S0169-5347(98) 01422-0.

Botstein D., White R.L., Skolnick M. \& Davies R.W. 1980. Construction of a genetic linkage map in man using restriction fragment length polymorphism. American Journal of Human Genetics 32, 314-331. 
CAFF \& PAME 2017. Arctic invasive alien species: strategy and action plan. Akureyri: The Conservation of Arctic Flora and Fauna / Protection of the Arctic Marine Environment.

Chase M.W., Cowan R.S., Hollingsworth P.M., Van den Berg C., Madrinan S., Petersen G., Seberg O., Jorgsensen T., Cameron K.M. \& Carine M. 2007. A proposal for a standardised protocol to barcode all land plants. Taxonomy 56, 295-299, doi: 10.1002/tax.562004.

Chen S., Yao H., Han J., Liu C., Song J., Shi L., Zhu Y., Ma X., Gao T., Pang X., Luo K., Li Y., Li X., Jia X., Lin Y. \& Leon C. 2010. Validation of the ITS2 region as a novel DNA barcode for identifying medicinal plant species. PLoS One 5, e8613, doi: 10.1371/journal.pone.0008613.

Ching A., Caldwell K.S., Jung M., Dolan M., Smith O.S., Tingey S., Morgante M. \& Rafalski A.J. 2002. SNP frequency, haplotype structure and linkage disequilibrium in elite maize inbred lines. BMC Genetics 3, article no. 19, doi: 10.1186/1471-2156-3-19.

Desfeux C. \& Lejeune B. 1996. Systematics of Euromediterranean silene (Caryophyllaceae): evidence from a phylogenetic analysis using ITS sequences. Comptes Rendus de l'Academie des Sciences, Paris, Sciences de le Vie/Life Sciences 319, 351-358.

Duan H., Wang W., Zeng Y., Guo M. \& Zhou Y. 2019. The screening and identification of DNA barcode sequences for Rehmannia. Scientific Reports 9, article no. 17295, doi: 10.1038/s41598-019-53752-8.

Eastwood R.J., Drummond C.S., Schifino-Wittmann M.T. \& Hughes C.E. 2008. Diversity and evolutionary history of Lupins-insights from new phylogenies. In J.A. Palta \& J.B. Berger (eds.): Lupins for health and wealth. Proceedings of the 12th International Lupin Conference. International Lupin Association, Fremantle, Western Australia, 14-18 September 2008. Pp. 346-354. Canterbury: International Lupin Association.

El Mousadik A. \& Petit R.J. 1996. High level of genetic differentiation for allelic richness among populations of the argan tree [Argania spinosa (L.) Skeels] endemic to Morocco. Theoretical and Applied Genetics 92, 832-839, doi: 10.1007/BF00221895.

Estoup A., Ravigné V., Hufbauer R., Vitalis R., Gautier M., Facon B. 2016. Is there a genetic paradox of biological invasion? Annual Review of Ecology, Evolution, and Systematics 47, 51-72, doi: 10.1146/annurev-ecolsys-121415-032116.

Feng S., Jiang M., Shi Y., Jiao K., Shen Ch., Lu J., Ying Q. \& Wang H. 2016. Application of the ribosomal DNA ITS2 region of Physalis (Solanaceae): DNA barcoding and phylogenetic study. Frontiers in Plant Science 7, article no. 1047, doi: 10.3389/fpls.2016.01047.

Finkeldey R. 1994. A simple derivation of the partitioning of genetic differentiation within subdivided populations. Theoretical and Applied Genetics 89, 198-200, doi: 10.1007/ BF00225141.

Finkeldey R. \& Murillo O. 1999. Contributions of subpopulations to total gene diversity. Theoretical and Applied Genetics 98, 664-668, doi: 10.1007/s001220051118.

Gallardo B., Bacher S., Bradley B., Comín F.A., Gallien L., Jeschke J.M., Sorte C.J.B. \& Vilà M. 2019. InvasiBES: understanding and managing the impacts of invasive alien species on biodiversity and ecosystem services. NeoBiota 50, 109-122, doi: 10.3897/neobiota.50.35466.

Gamache I., Jaramillo-Correa J.P., Payette S. \& Bousquet J. 2003. Diverging patterns of mitochondrial and nuclear DNA diversity in Subarctic black spruce: imprint of a founder effect associated with postglacial colonization. Molecular Ecology 12, 891-901, doi: 10.1046/j.1365-294X.2003.01800.x.

Goodall-Copestake W., Tarling G. \& Murphy E. 2012. On the comparison of population-level estimates of haplotype and nucleotide diversity: a case study using the gene cox 1 in animals. Heredity 109, 50-56. doi: 10.1038/hdy.2012.12.

Guðjohnsen S.K. \& Magnússon B. 2019. Útbreiðsla og flatarmál lúpinubreiða á Íslandi 2017. (Distribution and area occupied by lupin in Iceland 2017.) Garðabæ: Náttúrufræðistofnun Íslands.

Hamblin M.T., Warburton M.L. \& Buckler E.S. 2007. Empirical comparison of simple sequence repeats and single nucleotide polymosphism in assessment of maize diversity and relatedness. PLoS One 2, e1367, doi: 10.1371/ journal.pone.0001367.

Han J., Zhu Y., Chen X., Liao B., Yao H., Song J., Chen S. $\&$ Meng F. 2013. The short ITS2 sequence serves as an efficient taxonomic sequence tag in comparison with the full-length, ITS. BioMed Research International 2013, article no. 741476, doi: 10.1155/2013/741476.

Hartl D.L. \& Clark A.G. 1989. Principles of population genetics. 2nd edn. Sunderland, MA: Sinauer Associates.

Harvey-Samuel T. \& Ant T. \& Alphey L. 2017. Towards the genetic control of invasive species. Biological Invasions 19, 1683-1703, doi: 10.1007/s10530-017-1384-6.

Hedrick P. 2011 . Genetics of populations. Sudbury, MA: Jones $\delta$ Bartlett Learning.

Heuertz M., Fineschi S., Anzidei M., Pastorelli R., Salvini D., Paule L., Frascaria-Lacoste L., Hardy N., Vekemans O. \& Vendramin X.G.G. 2004. Chloroplast DNA variation and postglacial recolonization of common ash (Fraxinus excelsior) in Europe. Molecular Ecology 13, 3437-3452, doi: $10.1111 /$ j.1365-294X.2004.02333.x.

Hildebrand C.E., Torney D.C. \& Wagner R.P. 1992. Informativeness of polymorphic DNA markers. Los Alamos Science 20, 100-102.

Hufnagel B., Marques A., Soriano A., Marquès L., Divol F., Doumas P., Sallet E., Mancinotti D., Carrere S., Marande W., Arribat S., Keller J., Huneau C., Blein T., Aimé D., Laguerre M., Taylor J., Schubert V., Nelson M., Geu-Flores F., Crespi M., Gallardo K., Delaux P.M., Salse J., Bergès H., Guyot R., Gouzy J. \& Péret B. 2020. High-quality genome sequence of white lupin provides insight into soil exploration and seed quality. Nature Communications 11, article no. 492, doi: 10.1038/s41467-019-14197-9.

Hughes C.E., Eastwood R.J. \& Bailey C.D. 2006. From famine to feast? Selecting nuclear DNA sequence loci for plant species-level phylogeny reconstruction. Philosophical Transactions of the Royal Society B 361, 21 1-225, doi: 10.1098/ rstb.2005.1735.

Jeffries D.L., Copp G.H., Handley L.L., Olsén H.K., Sayer C.D. \& Hänfling B. 2016. Comparing RADseq and microsatellites 
to infer complex phylogeographic patterns, an empirical perspective in the Crucian carp, Carassius carassius, L. Biological Invasions 25, 2997-3018, doi: 10.1111/mec.13613.

Jogesh T., Peery R., Downie S.R. \& Berenbaum M.R. 2015. Patterns of genetic diversity in the globally invasive species wild parsnip (Pastinaca sativa). Invasive Plant Science and Management 8, 415-429, doi: 10.1614/ IPSM-D-15-00024.1.

Käss E. \& Wink M. 1997. Molecular phylogeny and phylogeography of Lupinus (Leguminosae) inferred from nucleotide sequences of the rbcL gene and ITS $1+2$ regions of rDNA. Plant Systematics and Evolution 208, 139-167, doi: 10.1007/BF00985439.

Kawuki R.S., Ferguson M., Labuschagne M., Herselman L. \& Kim D.-J. 2009. Identification, characterisation and application of single nucleotide polymorphisms for diversity assessment in cassava (Manihot esculenta Crantz). Molecular Breeding 23, 669-684, doi: 10.1007/ s11032-009-9264-0.

Kimura M. \& Crow J. 1964. The number of alleles that can be maintained in a finite population. Genetics 49, 725-738, doi: 10.1093/genetics/49.4.725.

Kollipara K.P., Singh R.J. \& Hymowitz T. 1997. Phylogenetic and genomic relationships in the genus Glycine Willd. based on sequences from the ITS region of nuclear rDNA. Genome 40, 57-68, doi: 10.1139/g97-008.

Kruglyak L. 1997. The use of a genetic map of biallelic markers in linkage studies. Nature Genetics 17, 21-24, doi: 10.1038/ng0997-21.

Książkiewicz M., Nazzicari N., Yang H., Nelson M.N., Renshaw D., Rychel S., Ferrari B., Carelli M., Tomaszewska M., Stawiński S., Naganowska B., Wolko B. \& Annicchiarico P. 2017. A high-density consensus linkage map of white lupin highlights synteny with narrow-leafed lupin and provides markers tagging key agronomic traits. Scientific Reports 7 , article no. 15335, doi: 10.1038/s41598-017-15625-w.

Kumar S., Stecher G., Li M., Knyaz C. \& Tamura K. 2018. MEGA X: molecular evolutionary genetics analysis across computing platforms. Molecular Biology and Evolution 35, 1547-1549, doi: 10.1093/molbev/msy096.

Lawson Handley L.-J., Estoup A., Evans D.M., Thomas C.E., Lombaert E., Facon B., Aebi A. \& Roy H.E. 2011. Ecological genetics of invasive alien species. Biological Control 56, 409-428, doi: 10.1007/s10526-011-9386-2.

Lewontin R.C. 1972. The apportionment of human diversity. Evolutionary Biology 6, 381-398, doi: 10.1007/ 978-1-4684-9063-3_14.

Li X., Yang Y., Henry R.J., Rosseto M., Wang Y. \& Chen S. 2015. Plant DNA barcoding: from gene to genome. Biological Reviews 90, 157-166, doi: 10.1111/brv.12104.

Mäder G., Zamberlan P.M., Fagundes N.J.R., Magnus T., Salzano F.M., Bonatto S.L. \& Freitas L.B. 2009. The use and limits of ITS data in the analysis of intraspecific variation in Passiflora L. (Passifloraceae). Genetics and Molecular Biology 33, 99-108, doi: 10.1590/S1415-47572009005000101.

Mishra P., Kumar A., Rodrigues V., Shukla A.K. \& Sundaresan V. 2016. Feasibility of nuclear ribosomal region ITS 1 over ITS2 in barcoding taxonomically challenging genera of subtribe Cassiinae (Fabaceae). PeerJ 4, e2638, doi: 10.7717/ peerj.2638.

Nei M. 1972. Genetic distance between populations. American Naturalist 106, 283-292, doi: 10.1086/282771.

Nei M. 1973. Analysis of gene diversity in subdivided populations. Proceedings of the National Academy of Sciences of the United States of America 70, 3321-3323, doi: 10.1073/ pnas.70.12.3321.

Nei M. 1987. Molecular evolutionary genetics. New York, NY: Columbia University Press.

Nei M. \& Kumar S. 2000. Molecular evolution and phylogenetics. New York, NY: Oxford University Press.

Nieto-Feliner G. \& Rosselló J.A. 2007. Better the devil you know? Guidelines for insightful utilization of nrDNA ITS in species-level evolutionary studies in plants. Molecular Phylogenetics and Evolution 44, 911-919, doi: 10.1016/j. ympev.2007.01.013.

Ohta T. 1982. Linkage disequilibrium due to random drift in finite subdivided populations. Proceedings of the National Academy of Sciences of the United States of America USA 79, 1940-1944, doi: 10.1073/pnas.79.6.1940.

Olgeirsson F.G. 2007. Sádmenn sandanna. Saga landgræðslu á Íslandi 1907-2007. (Sowers of the sands. History of land reclamation in Iceland 1907-2007.) Gunnarsholti: Landgræðsla Ríkisins.

Ott J. 1992. Strategies for characterizing highly polymorphic markers in human gene mapping. American Journal of Human Genetics 51, 283-290.

Qin Y., Li M., Cao Y., Gao Y. \& Zhang W. 2017. Molecular thresholds of ITS2 and their implications for molecular evolution and species identification in seed plants. Scientific Reports 7, article no. 17316, doi: 10.1038/ s41598-017-17695-2.

Richardson D.M., Pyšek P., Rejmanek M., Barbour M.G., Panetta F.D. \& West C.J. 2000. Naturalization and invasion of alienplants:conceptsanddefinitions.DiversityandDistributions 6, 93-107, doi: 10.1046/j.1472-4642.2000.00083.x.

Rozas J., Ferrer-Mata A., Sánchez-DelBarrio J.C., GuiraoRico S., Librado P., Ramos-Onsins S.E. \& SánchezGracia A. 2017. DnaSP 6: DNA sequence polymorphism analysis of large datasets. Molecular Biology and Evolution 34, 3299-3302, doi: 10.1093/molbev/msx248.

Salmaso M., Faes G., Segala C., Stefanini M., Salakhutdinov I., Zyprian E., Toepfer R., Grando M.S. \& Velasco R. 2004. Genome diversity and gene haplotypes in the grapevine (Vitis vinifera L) as revealed by single nucleotide polymorphisms. Molecular Breeding 14, 385-395, doi: 10.1007/ s1 1032-004-0261-z.

Schierbeck G. 1886. Skýrsla um nokkrar tilraunir til jurtaræktunar á Íslandi. (Report on some experiments in vegetable-growing in Iceland.) Tímarit Hins Íslenska Bókmenntafélag 7, 1-66.

Shannon C.E. \& Weaver W. 1949. The mathematical theory of communication. Urbana: University of Illinois Press.

Skorupski J., Szenejko M., Śmietana P., Panicz R., Keszka S., Czerniejewski P., Soroka M., Orłowska L., Albrycht M., Zatoń-Dobrowolska M., Moska M., Kirczuk L. \& Rymaszewska A. 2017. Invasive alien species-identification 
of threats to protect biodiversity. Szczecin: Green Federation Gaia / Polish Society for Conservation Genetics Lutreola. Smith A.L., Trevor R., Hodkinson T.R., Villellas J., Catford J.A., Csergö A.M., Blomberg S.P., Crone E.E., Ehrlén J., Garciak M.B., Lainel A-L., Roach D.A., Salguero-Gómezo R., Wardlep G.M., Childs D.Z., Elderd B.D., Finn A., Munné-Bosch S., Baudraza M.E.A, Bódis J., Brearley F.Q., Bucharova A., Caruso C.M., Duncan R.P., Dwyer J.M., Gooden B., Groenteman R., Hamre L.N., Helm A., Kelly R., Laanisto L., Lonati M., Moore J.L., Morales M., Olsen S.L., Pärtel M., Petry W.K., Ramula S., Rasmussen P.U., Enri S.R., Roeder A., Roscher Ch., Saastamoinen M., Tack A.J.M., Töpper J.P., Vose G.E., Wandrag E.M., Wingler A., Yvonne M. \& Buckleya Y.M. 2020. Global gene flow releases invasive plants from environmental constraints on genetic diversity. Proceedings of the National Academy of Sciences of the United States of America 117, 4218-4227, doi: 10.1073/pnas.1915848117.

Sonnante G., Galasso I. \& Pignone D. 2003. ITS sequence analysis and phylogenetic inference in the genus Lens Mill. Annales of Botany 91, 49-54, doi: 10.1093/aob/mcg007.

Stefansson R., von Schmalensee M. \& Skorupski J. 2016. A tale of conquest and crisis: invasion history and status of the American mink (Neovison vison) in Iceland. Acta Biologica 23, 87-100, doi: 10.18276/ab.2016.23-08.

Stout J.C., Duffy K.J., Egan P.A., Harbourne M. \& Hodkinson T.R. 2015. Genetic diversity and floral width variation in introduced and native populations of a long-lived woody perennial. AoB Plants 7, plu087, doi: 10.1093/ aobpla/plu087.

Stronen A.V., Iacolina L. \& Ruiz-Gonzalez A. 2019. Rewilding and conservation genomics: how developments in (re)colonization ecology and genomics can offer mutual benefits for understanding contemporary evolution. Global Ecology and Conservation 17, e00502, doi: 10.1016/j.gecco.2018. e00502.

Tajima F. 1983. Evolutionary relationship of DNA sequences in finite populations. Genetics 105, 437-460, doi: 10.1093/ genetics/105.2.437.

Tajima F. 1989. Statistical methods to test for nucleotide mutation hypothesis by DNA polymorphism. Genetics 123, 585-595, doi: 10.1093/genetics/123.3.585.

Thorsson J. \& Hlidberg K. 1997. Potential speciality products in Lupinus nootkatensis and some native Icelandic plant species. A. Quinolizidine alkaloids and the Nootka lupin. In L. Andreasen (ed.): Plant based speciality products and biopolymers. Pp. 147-155. Copenhagen: Nordic Council of Ministers.

Thuiller W., Albert C., Araújo M.B., Berry P.M., Guisan A., Hickler T., Midgley G.F., Paterson J., Schurr F.M., Sykes M.T. \& Zimmermann N.E. 2008. Predicting global change impacts on plant species distributions: future challenges. Perspectives in Plant Ecology, Evolution and Systematics 9, 137-152, doi: 10.1016/j.ppees.2007.09.004.

Tollefsrud M.M., Sønstebø J.H., Brochmann C., Johnsen Ø., Skrøppa T. \& Vendramin G.G. 2009. Combined analysis of nuclear and mitochondrial markers provide new insight into the genetic structure of North European Picea abies. Heredity 102, 549-562, doi: 10.1038/hdy.2009.16.

Varshney R.K., Beier U., Khlestkina E.K., Kota R., Korzun V., Graner A. \& Börner A. 2007. Single nucleotide polymorphisms in rye (Secale cereale L.): discovery, frequency and application for genome mapping and diversity studies. Theoretical and Applied Genetics 114, 1105-1116, doi: 10.1007/s00122-007-0504-6.

Vetter V.M.S., Tjaden N.B., Jaeschke A., Buhk C., Wahl V., Wasowicz P. \& Jentsch A. 2018. Invasion of a legume ecosystem engineer in a cold biome alters plant biodiversity. Frontiers in Plant Science 9, article no. 715, doi: 10.3389/ fpls.2018.00715.

Vyšniauskienė R., Rančelienė V., Žvingila D. \& Patamsytė J. 2011. Genetic diversity of invasive alien species Lupinus polyphyllus populations in Lithuania. Žemdirbystè 98, 383-390.

Wahlund S. 1928. Zusammensetzung von Population und Korrelation-serscheinung vom Standpunkt der Vererbungslehre aus betrachtet. (Composition of population and correlation phenomenon from the point of view of heredity.) Hereditas 11, 65-106, doi: 10.1111/j.16015223.1928.tb02483.x.

Wallace I.M., O'Sullivan O., Higgins D.G. \& Notredame C. 2006. M-Coffee: combining multiple sequence alignment methods with T-Coffee. Nucleic Acids Research 34, 1692-1699, doi: 10.1093/nar/gkl091.

Wang X., Xu Z., Yan C., Luo W., Wang R., Han X., Jiang Y. \& Li M.-H. 2017. Responses and sensitivity of N, P and mobile carbohydrates of dominant species to increased water, $\mathrm{N}$ and $\mathrm{P}$ availability in semi-arid grasslands in northern China. Journal of Plant Ecology 10, 486-496, doi: org/10.1093/jpe/rtw053.

Wang X., Zheng S. Liu Y. \& Han J. 2016. ITS2, a better DNA barcode than ITS in identification of species in Artemisia L. Chinese Herbal Medicines 8, 352-358, doi: 10.1016/ S1674-6384(16)60062-X.

Ward S.M., Gaskin J.F. \& Wilson L.M. 2008. Ecological genetics of plant invasion: what do we know? Invasive Plant Science and Management 1, 98-109, doi: 10.1614/ IPSM-07-022.1.

Wąsowicz P., Przedpelska-Wąsowicz E.M. \& Kristinsson H. 2013. Alien vascular plants in Iceland: diversity, spatial patterns, temporal trends, and the impact of climate change. Flora-Morphology Distribution Functional Ecology of Plants 208, 648-673, doi: 10.1016/j.flora.2013.09.009.

Watterson G.A. 1977. Heterosis or neutrality? Genetics 85, 789-814.

Weir B.S. 1990. Genetic data analysis. Sunderland, MA: Sinauer Associates.

White T.L., Adams W.T. \& Neale D.B. 2007. Forest genetics. Wallingford: CABI Publishing.

Whitlock M. \& McCauley D. 1999. Indirect measures of gene flow and migration: $\mathrm{FST} \neq 1 /(4 \mathrm{Nm}+1)$. Heredity 82, 117-125, doi: 10.1038/sj.hdy.6884960.

Willow J., Tamayo M. \& Jóhannsson M.H. 2017. Potential impact of Nootka lupin (Lupinus nootkatensis) invasion on 
pollinator communities in Iceland. Icelandic Agricultural Sciences 30, 51-54, doi: 10.16886/IAS.2017.06.

Wilson J.R.U., Dormontt E.E., Prentis P.J., Lowe A.J. \& Richardson D.M. 2009. Something in the way you move: dispersal pathways affect invasion success. Trends in Ecology OEvolution 24, 136-144, doi: 10.1016/j.tree.2008.10.007.

Wright S. 1931. Evolution in Mendelian populations. Genetics 16, 97-159, doi: 10.1093/genetics/16.2.97.

Wright S. 1943. Isolation by distance. Genetics 28, 114-138, doi: $10.1093 / \mathrm{nq} / 184.4 .114 \mathrm{~g}$.

Wright S. 1978. Evolution and the genetics of populations. Vol. 4. Variability within and among natural populations. Chicago, IL: University of Chicago Press.

Xu L., Myneni R.B., Chapin F.S. III, Callaghan T.V., Pinzon J.E., Tucker C.J., Zhu Z., Bi J., Ciais P., Tømmervik H., Euskirchen E.S., Forbes B.C., Piao S.L., Anderson B.T., Ganguly S., Nemani R.R., Goetz S.J., Beck P.S.A., Bunn A.G., Cao C. \& Stroeve J.C. 2013. Temperature and vegetation seasonality diminishment over northern lands. Nature Climate Change 3, 581-586, doi: 10.1038/NCLIMATE1836.

Yao H., Song J., Liu C., Luo K., Han J., Li Y., Pang X., Xu H., Zhu Y., Xiao P. \& Chen S. 2010. Use of ITS2 region as the universal DNA barcode for plants and animals. PLoS One 5, e13102, doi: 10.1371/journal.pone.0013102.

Yeh F.C. \& Boyle T.J.B. 1997. Population genetic analysis of co-dominant and dominant markers and quantitative traits. Belgian Journal of Botany 129, 157.

Yuan Y.M. \& Küpfer P. 1995. Molecular phylogenetics of the subtribe Gentianinae (Gentianaceae) inferred from the sequences of the internal transcribed spacers (ITS) of nuclear ribosomal DNA. Plant Systematics and Evolution 196, 207-226, doi: 10.1007/BF00982961.

Zar J.H. 2009. Biostatistical analysis. 5th edn. Upper Saddle River, NJ: Prentice Hall.

Zhao L.-L., Feng S.-J., Tian J.-Y., Wei A.-Z. \& Yang T.-X. 2018. Internal transcribed spacer 2 (ITS2) barcodes: a useful tool for identifying Chinese Zanthoxylum. Applications in Plant Sciences 6, e01157, doi: 10.1002/aps3.1157.

Zhou G., Jian J., Wang P., Li C., Tao Y., Li X., Renshaw D., Clements J., Sweetingham M. \& Yang H. 2018. Construction of an ultra-high density consensus genetic map, and enhancement of the physical map from genome sequencing in Lupinus angustifolius. Theoretical and Applied Genetics 131, 209-223, doi: 10.1007/s00122-017-2997-y. 